\title{
A hypothesis to relate salivary tumors with mammary and prostate neoplasias
}

\author{
Adriana B. Actis* \\ Instituto de Biología Celular, Facultad de Ciencias Médicas, Universidad Nacional de Córdoba, Casilla de Correo 220.5000 Córdoba, \\ Argentina ; Adriana B. Actis* - Email: adractis@odo.unc.edu.ar; Phone: +54-351-4334020; * Corresponding author \\ received April 15, 2005; revised April 16, 2005; accepted April 17, 2005; published online April 21, 2005
}

\begin{abstract}
:
Salivary, mammary and prostate glands are sex hormone-dependent organs sharing common aspects in structure, hormonal responsiveness and tumor histopathology. Salivary tumors (especially the malignant types) are not as frequent as mammary and prostate neoplasias. Hence, prognosis of some salivary tumors is not always efficient. Here, we review the oncology of salivary gland and its putative relation to breast/prostate tumors.
\end{abstract}

Keywords: glands; salivary; mammary; prostate; tumors; sex hormones; histopathology

\section{Background:}

Salivary glands comprise a group of minor and major glands lining the oral cavity and they secrete saliva. Saliva is a complex fluid like plasma reflecting in organic constituents. It is of use for the diagnosis and prognosis of certain diseases. [1, 2] Salivary glands share similar characteristics (morphology, sex hormone dependency, cellular mechanisms, and tumor histopathology) to breast and prostate. [3-8] Mammary and prostate tumors are among the most frequent in women and in men, respectively. Salivary tumors correspond to only $3 \%$ of all the neoplasms depending on the geographical prevalence unlike frequently seen mammary and prostrate cancers. [9] Malignant salivary tumors are infrequent and a good prognosis is not always available. Here, we review the association of salivary tumors with mammary and prostate neoplasias.

Relating salivary tumors with breast and prostate neoplasias:

Some authors showed that salivary gland tumors may be associated with other neoplasias, mainly breast and prostate tumors. This is especially referred to the increased number of second primary tumors. [3, 7] Evidences, although scarce, are discussed below.

\section{Second primary tumors:}

In humans, salivary glands are an elective site for second primary tumors of breast and prostate neoplasias. $[3,4]$ Thus, it was shown that women bearing a first primary salivary tumor (benign or malignant) have 4-5 fold increased risk of a second primary tumor in breast. [5] In coincidence with this finding, it was observed that rarely found multiple tumors (each one with identical or different histology) of the salivary glands appear simultaneously with extra-glandular tumors, especially breast carcinomas. [10] This fact would indicate an association between hormone dependent cancers, implying alertness in the follow-up of those patients. [3, 4]

\section{Metastatic tumors:}

Metastatic breast and prostate cancer dissemination also affects the parotid and submandibular glands. $[11,12,13,14]$

\section{Experimental evidence:}

There are experimental evidences pointing to the association between salivary and mammary tumorigenesis. For instance, occasional salivary tumors were seen in a model of mammary tumors (transgenic TG.SH mice: mouse mammary tumor virus/v-Ha-ras). [15]

Analogy with tumor histopathologic types:

Salivary, mammary and prostate glands share very similar histopathologic types of benign and malignant tumors. For example, pleomorphic adenomas and mucocele-like tumors of human breast are analogous in histology to the same entities of salivary glands. [16,17] Other tumors like adenomyoepitheliomas, acinic cell-like, mucoepidermoid carcinomas and salivary duct carcinoma of the breast are shown to be the counterpart of those of the salivary glands. $[18,19,20$, 21] In addition, salivary duct carcinoma is histologically similar to that of prostatic origin. [21]

\section{Influence of sex hormones:}

Like normal glands, neoplastic salivary glands are also hormone-dependent with increased steroid metabolism. [22, 23] Molteni et al., and Ozono et al., detected estradiol (E2) in salivary tumors (including benign pleomorphic adenomas). [24, 25] On the contrary, Gaffney et al., did not find estrogen receptor neither in benign nor in malignant parotid tumors. However, they detected E2 in breast cancer sections, being uncertain about its role in parotid tumor growth regulation. [26] The parotid gland contains steroid metabolizing enzymes which favor an oxidative reaction pathway, and the 17 beta-HSDH activity is significantly elevated in human neoplastic tissue. [23]

Salivary adenoid cystic carcinomas express progesterone receptors and are therefore of putative prognostic and therapeutic value. $[\mathbf{2 5}, 27]$ Testosterone and dihydrotestosterone associated with prostate tumors are negatively immunostained in human pleomorphic adenomas. [28, 29] Testosterone did not promote the development of carcinomas in DMBA-injected submandibular gland of murine. However, it 


\section{Bioinformation}

\author{
www.bioinformation.net
}

\section{Review Hypothesis}

increased the secretion of salivary epidermal growth factor

(EGF), a tumor-enhancing factor in mammary cancer. [30]

Polyoma virus inoculation appeared to induce salivary tumors in $70 \%$ and $30 \%$ of male and female mice, respectively. Testosterone treatment increased the tumor frequency in $69-90 \%$ of male mice. Nonetheless, orchidectomy (surgical removal of testicles) reduced it to $50 \%$. Oophorectomy (surgical removal of ovaries) as well as estrogen treatment had no effect on salivary gland tumor frequency in females. However, estrogen treatment was associated with breast second primary tumors in $60 \%$ of female animals bearing salivary gland tumors. [31]

\section{Conclusion:}

Tumors of salivary glands share very similar histopathological characteristics with breast and prostate neoplasias. They are also influenced by sex hormones. In addition, salivary glands seem to be an elective site for second primary tumors and metastatic lesions of breast and prostate, proposing that these neoplasias are associated with each other in tumorigenesis. Since the mechanism is not known, information leading to association will help in the diagnosis and prognosis of these related cancers.

\section{Acknowledgement:}

The author would like to thank the following persons: Dr. Raúl H. Colla for his valuable help; Prof. Mirta Valentich and Dr. Fabián Gómez Balangione for their critical reading of the manuscript.

\section{References:}

[01] R. F. Vining, et al., Clin Chem., 29 :1752 (1983) [PMID : 6225566]

[02] H. P. Lawrence, J Can Dent Assoc., 68:170 (2002) [PMID: 11911813]

[03] P. Prior, et al., Brit J Cance,. $36: 362$ (1977) [PMID; 921892]

[04] J. G. Schenker, et al., Cancer, 54:145 (1984) [PMID: 6722740]

[05] L. M. Abbey, et al., Oral Surg Oral Med Oral Pathol., 58: 682 (1984) [PMID: 6095160]

[06] T. Inui, et al., J Natl Cancer Inst., 81:1660 (1989) [PMID: 2795695]

[07] L. Napolitano, et al., Ann Ital Chir., $66: 719$ (1995) [PMID: 8948810]

[08] K. Kas, Verh K Acad Geneeskd Belg., 63:35 (2001) [PMID: 11284386]
[09] A. B. Actis, et al., Eur J Clin Nutr., 54 :805 (2000) [PMID: 11114673]

[10] G. Seifert, et al., Eur J Cancer B Oral Oncol., 32B:3 (1996) [PMID: 8729611]

[11] G. Vessecchia, et al., Virchows Arch., 427:349 (1995) [PMID: 7496606]

[12] E. Calvo-Boizas, et al., Acta Otorrinolaringol., Esp. 46: 391 (1995) [PMID: 8554814]

[13] R. H. Simpson, et al., Histopathology, 30:70 (1997) [PMID: 9023560]

[14] R. Hrebinko, et al., Urology, 41:272 (1993) [PMID: 7680177]

[15] Dardick, et al., Virchows Arch A Pathol Anat Histopathol., 421:105 (1992) [PMID: 1325087]

[16] M. Makek, et al., J Surg Oncol., 14:281 (1980) [PMID: 6248691]

[17] P. P. Rosen, Am J Surg Pathol., 10:464 (1986) [PMID: 3014913]

[18] M. Jabi, et al., Arch Pathol Lab Med., 112:73 (1988) [PMID: 2447854]

[19] F. Roncaroli, et al., Virchows Arch., 429:69 (1996) [PMID: 8865856]

[20] S. Leong, et al., Pathology, 17 : 516 (1985)

[21] H. E. Eriksen, et al., J Laryngol Otol., 101:636 (1987) [PMID: 3036982]

[22] W. Dimery, et al., Arch Otolaryngol Head Neck Surg., 113:1082 (1987) [PMID: 3620130]

[23] O. Djoseland, et al., J Steroid Biochem., 16:397 (1982) [PMID: 6953286]

[24] A. Molteni, et al., Arch Surg., 116 :207 (1981) [PMID: 6258538]

[25] S. Ozono, et al., Cell Struct Funct., 17:169 (1992) [PMID: 1322800]

[26] E. V. Gaffney, et al., Endocr Res., 21:635 (1995) [PMID: 7588432]

[27] P. C. Shick, et al., Oral Surg Oral Med Oral Pathol Oral Radiol Endod., 80:440 (1995) [PMID: 8521108]

[28] O. W Brawley, Urol Oncol., 21:67 (2003) [PMID: 12684130]

[29] T. Onitsuka, Acta Otolaryngol., 114:218 (1994) [PMID: 8203205]

[30] Y. Yura, et al., J Oral Pathol., 24 :303 (1995) [PMID: 7473266]

[31] P. J. Lamey, et al., J Oral Pathol., $14: 414$ (1985) [PMID: 2989467]

Edited by P. Kangueane

Citation: Actis, Bioinformation 1(1) : 12-13 (2005)

License statement: This is an open-access article, which permits unrestricted use, distribution, and reproduction in any medium, for non-commercial purposes, provided the original author and source are credited. 